\title{
KONSEP MANUSIA DALAM AL-QUR'AN (Telaah Kritis tentang Makna dan Eksistensi)
}

\author{
Dudung Abdullah \\ Fakultas Syariah dan Hukum Universitas Islam Negeri (UIN) Alauddin Makassar
}

\begin{abstract}
:
Humans are the best creatures of God's creation. Humans in the redaction of verses of the Qur'an have several terms, such as al nas, al ins, al insan, and Banu Adam. From these terms some of its meaning can be revealed which gives information about the origin of human creation and its behavior. Human existence generally serves as a servant of Allah (Abd.Allah) and as a guidance or prosper on the surface of the earth (Caliph of Allah).
\end{abstract}

Keywords:

Al-Insan: Man

\begin{abstract}
Abstrak:
Manusia adalah makhluk terbaik ciptaan Tuhan. Manusia dalam redaksi ayat Al Quran mempunyai beberapa term, seperti al nas, al ins, al insan, dan Bani Adam. Dari term-term tersebut sebagian maknanya bisa terungkap yang memberi informasi tentang asal penciptaan manusia dan perilakunya. Eksistensi Manusia secara umum berperan sebagai hamba Allah (Abd.Allah) dan sebagai pengayom atau pemakmur di permukaan bumi (khalifah Allah).
\end{abstract}

Kata Kunci:

Al-Insan: Manusia

\section{A. LATAR BELAKANG}

$\mathrm{P}$ erhatian umat Islam terhadap Al Quran terasa semakin besar. Hal itu terlihat dari berbagai gagasan yang dilontarkan para pakar, seperti dalam bentuk seruan untuk kembali menelaah ayat-ayat Al Quran (Rethingking Quran/ Al Ruju' lla Al Quran)1.

Penelitian terhadap ayat-ayat Al Quran atau terhadap kitab-kitab tafsir tak kunjung berakhir, antara lain disebabkan penemuan informasi baru berjalan secara

${ }^{1}$ Abd.Muin Salim, Metodologi Tafsir, Sebuah Rekonstruksi Epistimologis, Memantapkan Keberadaan Ilmu Tafsir Sebagai Disiplin Ilmu (Ujungpandang: IAIN Alauddin, 1999), h.1. Lihat Nashr Abu Zayd, Rethinking The Quran To wards a Humanistic Hermeneutic (Amsterdam: Humanistic Press, 2004), h.52. Lihat juga Zakiuddin Baidhawy, Al Ruju ila Al Quran; dari kekebalan Fondasionalisme Menuju Pencerahan Hermeneutis "Dalam Pradana Boy M. Hilmi Faig (Ed.), Kembali ke Al Quran Menafsir Makna Zaman (Malang: UMM Press, 2004)", h.3 
evolusi yang dipengaruhi oleh perkembangan ilmu pengetahuan, budaya dan perkembangan zaman.

Banyak pesan Al Quran bagi ilmuan (Ulu $A l$ albab) ${ }^{2}$ untuk mengkaji alam dan fenomenanya dan menemukan misteri-misteri ciptaan Tuhan. Ilmuan ini hendaklah menggunakan kemampuan indera dan intelektual (al hawas wa al-aql) secara bersamaan ${ }^{3}$ yang dikenal juga dengan cara rasionalisme dan empirisme ${ }^{4}$.

Salah satu informasi penting antara lain tentang manusia. Berpikir tentang manusia merupakan usaha yang berat, sebab meskipun pada masa kini sudah muncul ilmu seperti biologi, embriologi, psikologi, antropologi, dan sebagainya, namun belum mampu mengungkap semua misteri yang ada pada manusia ${ }^{5}$.

Berbagai teori telah dilontarkan, tentang asal usul manusia dan perkembangan manusia, seperti teori evolusi oleh Charles Darwin, perjalanan Darwin dilanjutkan oleh Sigmund Freud ${ }^{6}$ yang mendapat sorotan dari para ilmuwan lainnya, terutama sorotan negatif terhadap kesimpulan-kesimpulannya yang kontroversial. Sorotan dan analisis ilmu pengetahuan semakin meningkat sejak masa Renaisance yang mengakibatkan kekaguman yang berlebihan kepada otoritas sains yang terlepas dari nilai-nilai spiritual keagamaan.

Pendapat lainnya tentang misteriusnya makhluk manusia seperti yang dikemukakan oleh Alexis Carrel, pemenang hadiah Nobel dalam bukunya Man the Unknown bahwasanya manusia adalah makhluk yang kompleks, sehingga tidaklah mudah untuk mendapatkan satu gambaran untuknya, tidak ada satu cara untuk memahami makhluk ini secara utuh ataupun dalam bagian-bagiannya ${ }^{7}$.

Sikap ilmuan religius atau cendikiawan muslim tentunya menyatakan bahwa untuk mengetahui manusia yang misterius itu, tidak hanya dibutuhkan ilmu pengetahuan umum atau sains, tetapi juga sangat dibutuhkan dan diandalkan informasi dari Allah Swt melalui wahyu-Nya Al Quran.

Di dalam Al Quran hal terbaik yang dituntut di bidang ilmu ialah dorongannya kepada manusia supaya berpikir. Dalam ayat-ayatnya tidak terdapat suatu ketetapan yang sifatnya mematikan akal untuk memikirkan kandungannya ${ }^{8}$ serta menambah wawasan sedalam-dalamnya.

${ }^{2}$ Lihat misalnya Q.S. Ali Imran (3): 190, QS. Sad (38):29

${ }^{3}$ Lihat Taba Taba'̄', dalam Mahdi: Ghulsyani, The Holy Quran and The Science of The Nature, diterjemahkan Agus Efendi dengan judul, Filsafat Sains Menurut Al Quran (Bandung: Mizan, 1998), h.144 dan Lihat Muhammad Yusuf Musa, Al Quran Wa Al Falsafah, (Mesir: Dar Al Ma'arif, 1996), h.50

${ }^{4}$ Harun Nasution, Filsafat Agama, (Jakarta: Bulan Bintang, 1989), h.8

${ }^{5}$ Lihat Louis Leahay, Manusia Sebuah Misteri:, Sintesa Filosofis tentang Makhluk Islam in The Writings of El Gazali (Cairo: Dar El Maaref, 1960), h.213-215

${ }^{6}$ Lihat M.Quraish Shihab, Membumikan Al Quran (Bandung: Mizan, 1992), h.67

${ }^{7}$ Lihat Maurice Baucaille, What is The Origin of Man, The Answer of Science and The Holy Scriptures, diterjemahkan Rahmani Astuti, Asal Usul Manusia Menurut Bible, Al Quran dan Sains, (Bandung: Mizan, 1998), h.16

${ }^{8}$ Abbas Mahmud Al Akkad, Al Falsafah Al Qurani (Kairo: Dar al Hilal, t.th), h.10-13 
Al Quran dengan wawasannya yang amat luas banyak berbicara tentang manusia, kodrat dan kedudukannya ${ }^{9}$ dengan kedalaman dan kepekaan cita rasa bahasa Arab sehingga dalam setiap pernyataannya mengundang para pembacanya untuk bertadabbur, tabashur, tadzakkur dan tafakkur ${ }^{10}$.

Penelitian melalui daya nalar dan melalui perenungan yang mendalam terutama manusia sejak ia diciptakan hingga tampak di pentas kehidupan, sebagaimana dinyatakan dalam Al Quran QS. Al-Thariq (86):5

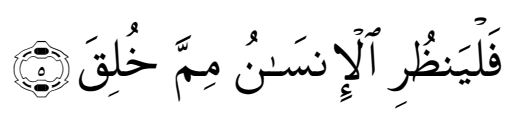

"Maka hendaklah manusia memperhatikan dari Apa Dia diciptakan?"

Dan QS. Al Dzariat (51): 21

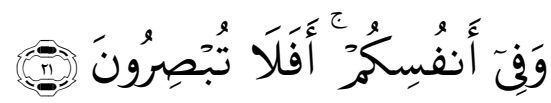

"Dan pada dirimu sendiri, Apakah kamu tidak memperhatikan?"

Manusia yang berasal dari nuthfah atau dari turab dengan proses yang ajaib berubah dewasa dan bertebaran di muka bumi ${ }^{11}$.

Manusia yang hadir sebagai makhluk fisika berbeda dengan jin sebagai makhluk metafisika, dalam kehidupannya mendapat predikat "ahsan al taqwim" (dalam bentuk yang sebaik-baiknya) ${ }^{12}$ dengan sebutan "Al Hayawan al-Natiq" manusia memiliki keterampilan berpikir dan berbicara yang mampu mengekspresikan dirinya dalam mempertahankan hidup dalam pergaulan.

Sebagai makhluk yang berakal manusia juga diberi sebutan yang bergengsi yaitu ulu al-albab. "Sebagai penyandang ulu al-albab manusia tidak hanya memiliki sikap ontologis tetapi juga sikap aksiologis ${ }^{13}$. Manusia yang tersusun dari dua unsur, materi dan immateri, jasmani dan rohani. Tubuh manusia berasal dari tanah dan ruh atau jiwa berasal dari substansi immateri di alam gaib ${ }^{14}$. Eksistensi manusia dewasa ditantang kemampuannya untuk merenungkan dan berpikir tentang dirinya, orang lain dan juga jagat raya, untuk menjadikan semua itu bermakna dan bermanfaat.

Demikian juga manusia sebagai makhluk terhormat memikul beban "khalifah Allah dan hamba Allah"15 untuk bisa memperjuangkan hak-hak kemanusiaan

${ }^{9}$ Lihat Abd.Muin Salim, Konsepsi Kekuasaan Politik dalam Al Quran, Cet.I (Jakarta: Raja Grafindo, 1994), h.81-92

${ }^{10}$ Yusuf Qardawi, Al Aqlu wa al Ilmu, diterjemahkan Abdul Hayyie Kattani et.al, dengan judul Al Quran berbicara tentang Akal dan Ilmu Pengetahuan (Jakarta: Gema Insani Press, 1998), h.64

${ }^{11}$ Lihat misalnya QS. Al Rum (30):20

${ }^{12}$ Lihat misalnya QS. Al Tin (95):4

${ }^{13}$ Lihat Dawam Raharjo, Paradigma Al Quran, Metodologi Tafsir \& Kritik Sosial (Jakarta: PSAP Muhammadiyah, 2005), h.9. Lihat misalnya QS. Ali Imran (3): 190, QS. Sad (38):29

14 Lihat misalnya QS. Al Sajadah (32): 7-9, dan lihat Harun Nasution, Islam Rasional (Bandung: Mizan,1996), h.37

${ }^{15}$ Lihat misalnya QS. Al Baqarah (2): 30, QS. Al An'am (6):165, lihat Zalbawi Soejoeti (et.al), Islam dan Iptek (Jakarta: PT. Raja Grafindo Persada,1998), h.41 
dengan menikmati kehidupan dan memperoleh kesejahteraan di dunia ini dengan cara terhormat ${ }^{16}$ tidak melampaui batas atau melanggar norma-norma hukum, karena salah satu kelemahan manusia adalah melampaui batas (QS.Al Alaq (96):6).

Untuk pembahasan lebih lanjut tentang manusia nampaknya perlu meneliti term-term manusia dalam Al Quran seperti insan/ins, basyar dan bani Adam ${ }^{17}$ dalam redaksi ayat dengan disertai pendapat para pakar tafsir, maka untuk maksud tersebut, makalah ini berusaha mendeskripsikan makna manusia dan perannya dalam panggung kehidupan dengan pendekatan filsafat qurani.

\section{B. RUMUSAN MASALAH}

Berdasarkan latar belakang masalah di atas dapat dikemukakan permasalahanpermasalahan penting, antara lain:

1. Apa makna dan hakikat manusia?

2. Bagaimana potensi dan eksistensi manusia?

\section{MANUSIA DAN HAKIKAT MANUSIA}

Manusia memiliki beberapa term yang dapat digunakan dalam Al Quran seperti insan/ins/al-nas, basyar dan bani Adam. Untuk lebih jelasnya, berikut ini dipaparkan penelusuran makna term-term tersebut.

\section{Makna al-Insan/al-ins/al-nas (الانسان - الانس - الناس)}

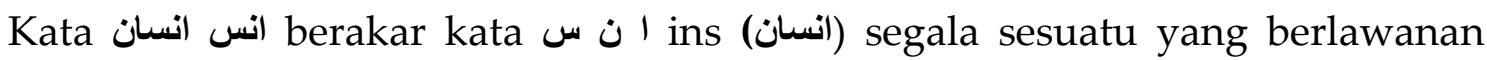
dengan cara liar18, tidak biadab, tidak liar, jinak, dinamis, harmonis, dan bersahabat ${ }^{19}$. Kata al-ins (الانس) biasanya berdampingan dengan kata al-jin (الجن). Manusia "al-ins" makhluk yang nampak secara fisik ini sedangkan jin makhluk yang tidak nampak (metafisik) ${ }^{20}$. Metafisik di sini identik dengan liar atau bebas, karena jin tidak mengenal ruang dan waktu.

Dengan sifat kemanusian itu, manusia berbeda dengan jenis makhluk lain yang metafisis, yang asing, yang tidak berkembang biak dan tidak hidup seperti manusia biasa.

Dalam Al Quran kata ins (نس (ن) terulang 10 kali, 12 ayat diantaranya berdampingan dengan kata "jin" (جن) (جن) Jin adalah jenis makhluk bukan manusia yang hidup di alam antah beranta dan alam yang terindera. Di balik dinding alam

${ }^{16}$ Lihat misalnya QS. Al Baqarah (2): 36, QS. Al Araf (7):24, dan lihat Abd.Muin Salim, Al Huquq al Insaniyah fi Al Quran al Karim (Makassar: Al Mu’tamar al Dawli/International Confrence,1-3 June,2001), h.2

17 Aisyah Abd.Rahman Bintu Syathi, Manusia dalam Prespektif Al Quran (Jakarta: PT. Pustaka Firdaus, 1999), h.1. lihat juga M. Quraish Shihab, Wawasan Al Quran (Bandung: Mizan, 1996), h.278-279

\footnotetext{
${ }^{18}$ Abi Al Husain Ahmad Bin Faris bin Zakariya, Al Maqayis al Lugah, I (t,t.: Dar Fikr, t.th.), h.145

${ }^{19}$ Ibrahim Anis, et.al., Al Mu'jam al Wasith, Juz I (Kairo:t.p), h.29. dan Lihat Al Ragib Al Asfahani, Mufradat Alfaz Al Quran (Beirut: Dar Al Syamiyah, 1992), h.94

${ }^{20}$ Aisyah Abd.Rahman Bint Syathi, Manusia dalam Perspektif Al Quran, h.5

${ }^{21}$ Muh.Fuad Abd.Al Baqi, Al Mu’jam al Mufahras li Alfaz al Quran (Beirut: Dar al Fikr, 1987), h.93
} 
kita manusia dan dia tidak mengikuti hukum-hukum. Hukum yang dikenal dalam tata kehidupan manusia ${ }^{22}$.

Kata insan (نسان) tentang 70 kali, ${ }^{23}$ kata: al-nas (ناس) terulang 240 kali24. Term "al-nas" secara umum menggambarkan manusia universal netral tanpa sifat. Sifat tertentu yang membatasi atau mewarnai keberadaannya, sedangkan kata "insan" pada umumnya menggambarkan makhluk manusia dengan berbagai potensi dan sifat ${ }^{25}$, makna-makna dari akar kata di atas paling tidak memberikan gambaran sepintas tentang potensi atau sifat makhluk tersebut, yakni ia memiliki sifat lupa, kemampuan bergerak yang melahirkan dinamika. Ia juga adalah makhluk yang selalu atau sewajarnya melahirkan rasa senang, harmonis dan kebahagiaan kepada pihak-pihak lain.

Term al-nas (الناس) menggambarkan manusia yang universal netral sebagai makhluk sosial seperti pernyataan Al Quran QS. Al Hujurat (49): 13

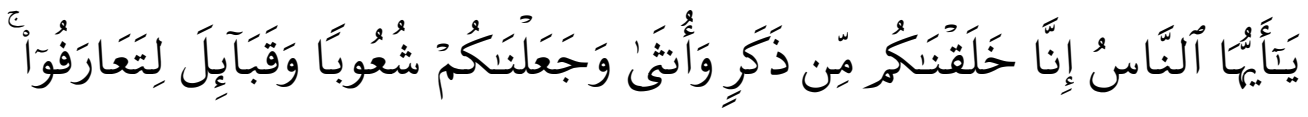

"Hai manusia, sesungguhnya Kami menciptakan kamu dari seorang laki-laki dan seorang perempuan dan menjadikan kamu berbangsa-bangsa dan bersuku-suku supaya kamu saling kenal-mengenal".

Berbeda dengan kata "al-nas" term "insan" yang secara umum menggambarkan manusia yang memiliki potensi atau sifat yang beragam, baik sifat positif maupun negatif. Perhatikan Firman Allah:

QS. Al Alaq (96): 4-5

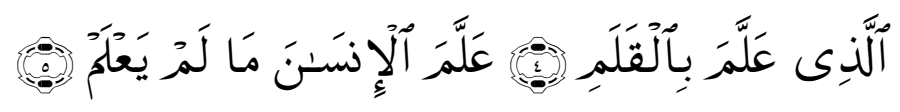

"Yang mengajar (manusia) dengan perantaran kalam, Mengajarkan kepada manusia apa yang tidak diketahuinya.

QS. Al Alaq (96): 6

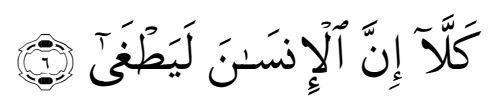

"Ketahuilah! Sesungguhnya manusia benar-benar melampaui batas".

Pada ayat 4-5 QS. Al Alaq di atas, Allah Swt menegaskan tentang pemberian ilmu melalui "qalam"26 (tulisan). Ini merupakan salah satu anugrah terbesar karena dengan tulisan satu generasi terdahulu dapat mentransfer ilmu dan pengalamannya

${ }^{22}$ Aisyah Abd.Rahman Bintu Syathi, Manusia dalam Prespektif Al Quran, h.6

${ }^{23}$ Muhammad Fuad Abd.Al Baqi, Al Mu'jam al Mufahras, h.93

${ }^{24}$ Muhammad Fuad Abd.Al Baqi, Al Mu'jam al Mufahras, h.726-729

${ }^{25}$ Muhammad Quraish Shihab, Tafsir al Quran al Karim, Tafsir atas surat-surat pendek berdasarkan urutan turunnya wahyu (Bandung: Pustaka Hidayah, 1997), h.87 dan Lihat Al Ragib Al Asfahani, Mufradat Alfaz al Quran (Beirut: Dar al Dar Syamiyah), h.94

${ }^{26} \mathrm{Al}$ Ragib Al Asfahani, Mufradat Alfaz al Quran, h.580,dan h. 683 
kepada suatu generasi yang akan datang kemudian. Sebagai penerima ilmu, manusia (al-insan) ini memiliki potensi dan sifat positif.

Sedangkan ayat 6 QS.Al Alaq tersebut menandakan bahwa manusia juga memiliki potensi atau sifat negatif yaitu يطغى yakni melampaui batas( تجاوز الحد فى الثيان )$^{27}$ dengan cara melanggar hukum dan aturan-aturan yang menjerumuskan ke lembah dosa.

\section{Makna Basyar}

Kata "بشر" yang terdiri dari huruf huruf ب ش ب yang arti dasarnya ${ }^{28}$ tampaknya sesuatu baik dan indah. Kata "basyar" juga berarti menggembirakan, menguliti, memperlihatkan dan mengurus sesuatu29. Al Raghib Al Ashfahani mengatakan bahwa "basyar" berarti al-jild (kulit). Manusia disebut basyar karena kulitnya terlihat jelas, berbeda dengan binatang, kulitnya tidak tampak karena tertutup oleh bulu ${ }^{30}$. Dengan demikian manusia yang sudah jelas di akui keberadaannya itulah yang disebut basyar.

Bintu syathi menyatakan bahwa basyar adalah manusia yang sudah diakui keberadaannya manusia dewasa, namun kedewasaan secara jasmani (fisiologis dan biologis) tanpa kedewasaan rohani (psikis). Pernyataan ini didasarkan pada penelusuran ayat tentang basyar dalam susunan redaksi (tarkib) yang menggunakan kata "mitslu"31 yang berarti seperti. Perhatikan QS Al Kahfi (18): 110

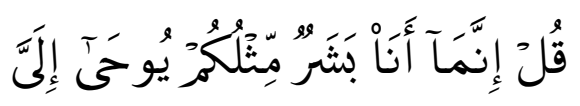

“Katakanlah:

Sesungguhnya aku ini hanya seorang manusia seperti kamu, yang diwahyukan kepadaku."

Basyar dalam ayat seperti ini, menurut Bintu Syathi adalah manusia anak turunan Adam, makhluk fisik yang suka makan dan jalan-jalan ke pasar. Aspek fisik itulah yang membuat pengertian basyar mencakup anak turunan Adam keseluruhan ${ }^{32}$.

Berbeda dengan Bintu Syathi, H.A Muin Salim menuturkan dalam Al Quran ditemukan 32 kali kata "basyar" adalah manusia dewasa secara fisik dan psikis (biologis dan kejiwaan), sehingga dia mampu bertanggung jawab, sanggup diberikan beban keagamaan bahkan mampu menjalankan tugas khalifah ${ }^{33}$.

${ }^{27}$ Lihat Mahmud Bin Umar Al Zumaksyari, Tafsir Al Kasysyaf, Jilid IV (t.t: Dar al Fikr,t.h), h.158-159

${ }^{28} \mathrm{Abi}$ Al Husain Ahmad bin Faris bin Zakariya, Maqayis al Lugah, I, H.251

${ }^{29}$ Al Ragib Al Asfahani, Mufradat Alfaz al Quran, h.124, dan lihat Abd.Muin Salim, Konsepsi Politik, h. 85

${ }^{30} \mathrm{Al}$ Ragib Al Asfahani, Mufradat Alfaz al Quran, h.124

${ }^{31}$ Lihat Muhammad Fuad Abd.Al Baqi, Al Mu'jam al Mufahras, h.120-121, dan juga Aisyah Bintu Syathi, Manusia dalam Prespektif Al Quran, h.2

${ }^{32}$ Aisyah Bintu Syathi, Manusia dalam Prespektif al Quran, h.2, dan h.37

${ }^{33}$ Abd.Muin Salim, Fitrah Manusia dalam Al Quran (Ujungpandang: Lembaga Studi Kebudayaan Islam (LSKI), 1990), h.22. lihat juga Ibrahim Madkour, The Concept of Man in Islamic Tought, cet. II (London: t.p.,1996), h.452 
H.A. Muin Salim berangkat dari term basyar seperti QS. Al Rum (30): 20

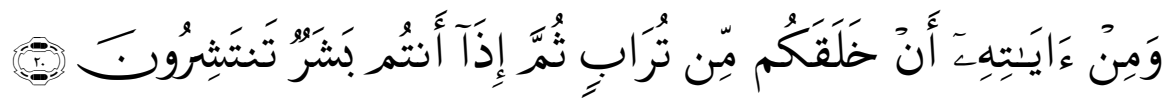

"Dan di antara ayat-ayat-Nya adalah ia menciptakan kamu dari tanah (turab) kemudian kamu menjadi manusia (basyar) yang bersebar".

Demikian juga QS. Ali Imran (3): 47 dan QS Al Maryam (19): 20 dengan klausanya berbunyi

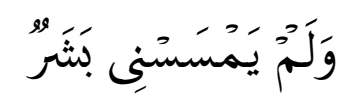

"Padahal aku belum pernah disentuh oleh manusia (basyar)".

Ayat di atas QS Al Rum (30): 20 menunjukkan perkembangan kehidupan manusia (basyar), karena dalam ayat tersebut dikemukakan min yang bermakna ibtida dan lafadz tsumma yang bermakna tatib $m a^{\prime} a$ tarakhị $i^{34}$, artinya peruntutan dan perselangan waktu.

Dari pernyataan tersebut dapat dipahami bahwa kejadian manusia diawali dari tanah kemudian cara berangsur-angsur mencapai kesempurnaan kejadiaannya ketika ia telah dewasa.

Kedewasaan dan tanggung jawab ${ }^{35}$ bisa juga menggunakan metode munasabah ayat dengan adanya keterkaitan suatu konsep ${ }^{36}$ seperti QS. Al Rum (30): 20

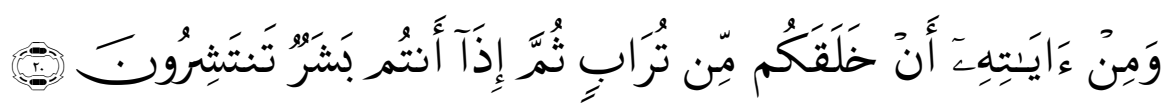

Dihubungkan dengan QS. Al Hijr (15): 28

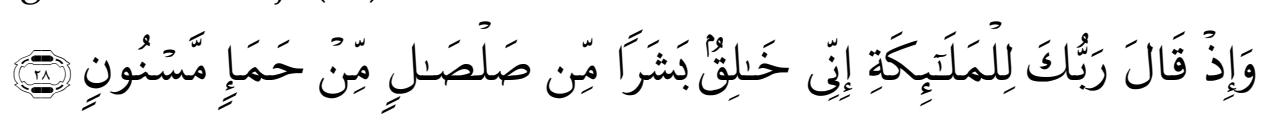

Selanjutnya dihubungkan dengan QS. Al Baqarah (2): 30

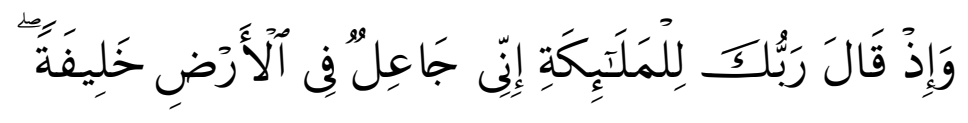

\section{Makna Bani Adam}

Kata Bani ( بنى ) berasal dari kata ban a- (بنى ) artinya membina, membangun, mendirikan, menyusun. Jadi Bani Adam artinya susunan keturunan anak cucu anak Nabi Adam dan generasi selanjutnya.

${ }^{34}$ Badaruddin Muhammad Ibnu Abdillah Al Zarkasyi, Al Burhan fi Ulum Al Quran (Mesir: Dar Ihya al Kutub Al Arabiyah), h.415

${ }^{35}$ Lihat Ahmad Mustafa Al Maragi, Tafsir Al Maragi, Juz XXI (Mesir: Mustafa Al Babī Al Halabī wa Auladuh,t.th) h.37 dan lihat Muhammad Hijazi, Tafsir Al Wadih, Juz XI (Kairo: Al Istiqlal al Kubra, 1968), h.22

${ }^{36}$ M.Quraish Shihab, Wawasan Al Quran, (Bandung: Miza, 1996), h.280 dan Abd.Muin Salim, Konsepsi Politik, h.86-87

${ }^{37}$ Al Ragib Al Asfahani, Mufradat Alfaz al Quran, h.148 
Dalam Al Quran term Bani Adam terdapat enam kali terulang ${ }^{38}$, seperti bunyi ayat dalam QS. Al Isra (17): 70

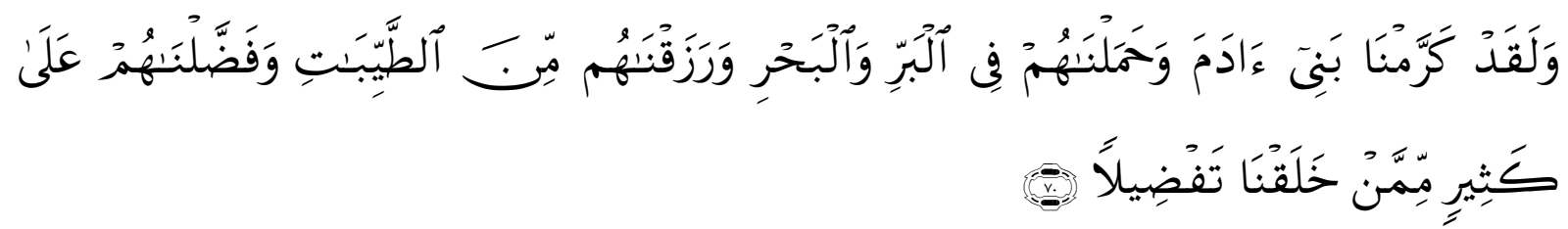

"Dan Sesungguhnya telah Kami muliakan anak-anak Adam, Kami angkut mereka di daratan dan di lautan, Kami beri mereka rezki dari yang baik-baik dan Kami lebihkan mereka dengan kelebihan yang sempurna atas kebanyakan makhluk yang telah Kami ciptakan."

Kemuliaan manusia sebagai Bani Adam dibanding dengan makhluk lainnya, termasuk makhluk jin dan malaikat, hal ini bisa dilihat serangkaian deskripsi QS. Al Hijr (15):29

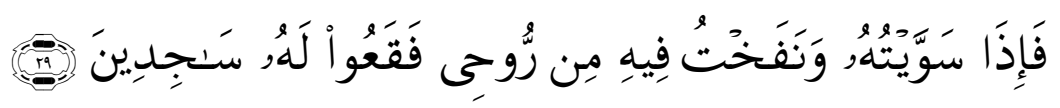

"Maka apabila aku menyempurnakan kejadiannya, dan telah meniup kan kedalamnya ruh (ciptaan)-Ku, Maka tunduklah kamu kepadanya dengan bersujud."

Dari permulaan kehadiran anak cucu Adam (manusia) seperti halnya hewan di bumi ini, hanya manusia yang mencapai tahapan Adam yang mampu memikul tanggung jawab. "Beberapa pemikir mengatakan, manusia lah yang beradab, sedangkan jin adalah makhluk yang tidak beradab ${ }^{39}$. Namun manusia/insan ini pun ada tingkatan-tingkatannya. Manusia yang sudah mencapai tingkatan Adam, masih terus berlanjut dan akan berakhir dengan kondisi yang lebih tinggi dibanding Adam. Dari beberapa term di atas dapat dipadukan bahwa manusia adalah ciptaan Tuhan sebagai keturunan Adam yang jelas wujudnya, mampu berbicara dan berpikir serta hidup dalam komunitas kemasyarakatan.

\section{ASAL-USUL PENCIPTAAN MANUSIA DAN EKSISTENSINYA}

\section{Asal-usul Penciptaan Manusia}

Dengan tugas Al Quran menuntut manusia yang hidup untuk memperhatikan penciptaan dirinya, QS. Al Thariq (86): 5

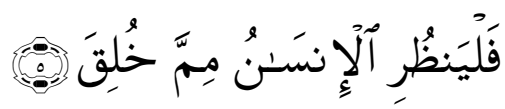

"Maka hendaklah manusia memperhatikan dari Apakah Dia diciptakan?"

\footnotetext{
${ }^{38}$ Muh.Fuad Abd.Al Baqi, Al Mu'jam al Mufahras, h.93

${ }^{39}$ H.G.Sarwar, Filsafat Al Quran, (Jakarta: Rajawali Pers, 1990), h.109
} 
Tuntutan ini diarahkan "Al Quran dengan informasi yang bervariasi dalam berbagai ayat. Penciptaan yang eksklusif yang berbeda dengan penciptaan manusia pada umumnya adalah Adam dan Isa, sebagaimana dinyatakan QS. Ali Imran (3): 59

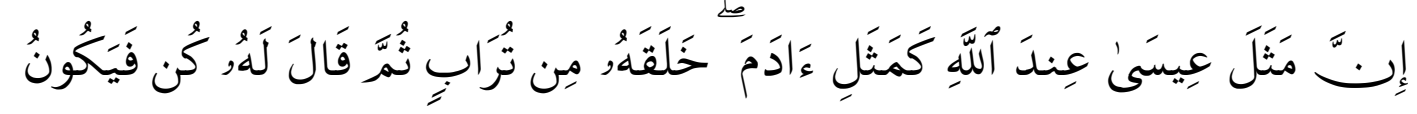

"Sesungguhnya misal (penciptaan) Isa di sisi Allah, adalah seperti (penciptaan) Adam. Allah menciptakan Adam dari tanah, kemudian Allah berfirman kepadanya: "Jadilah" (seorang manusia), Maka jadilah Dia."

Senada dengan ayat tersebut, dengan penambahan informasi yang lebih lengkap, sebagaimana penuturan QS. Al Sajadah (32): 7-9

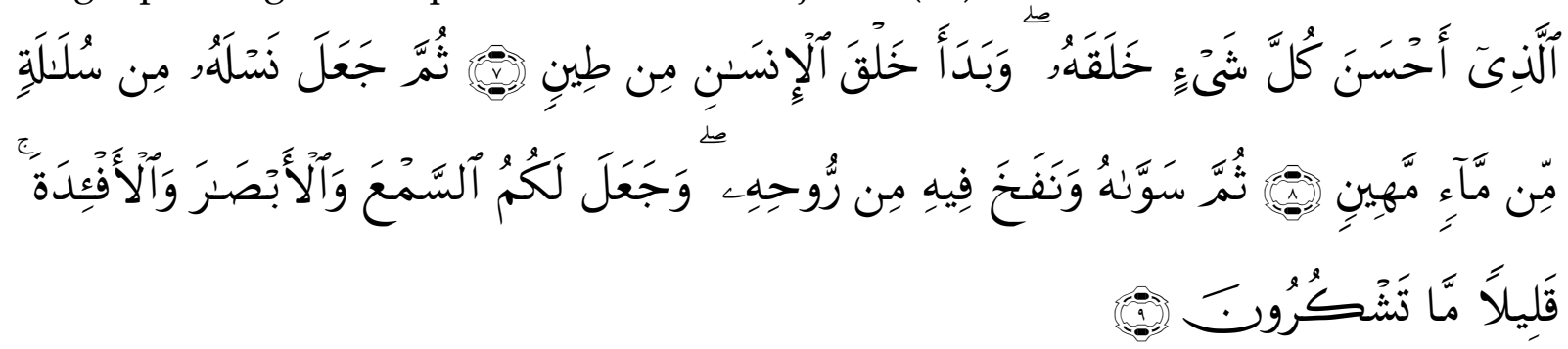

7. Yang membuat segala sesuatu yang Dia ciptakan sebaik-baiknya dan yang memulai penciptaan manusia dari tanah.

8. Kemudian Dia menjadikan keturunannya dari saripati air yang hina (air mani).

9. Kemudian Dia menyempurnakan dan meniupkan ke dalamnya roh (ciptaan)-Nya dan Dia menjadikan bagi kamu pendengaran, penglihatan dan hati; (tetapi) kamu sedikit sekali bersyukur.

Penciptaan manusia secara bertahap, Al Quran QS Al Mu'minun (23): 12-14

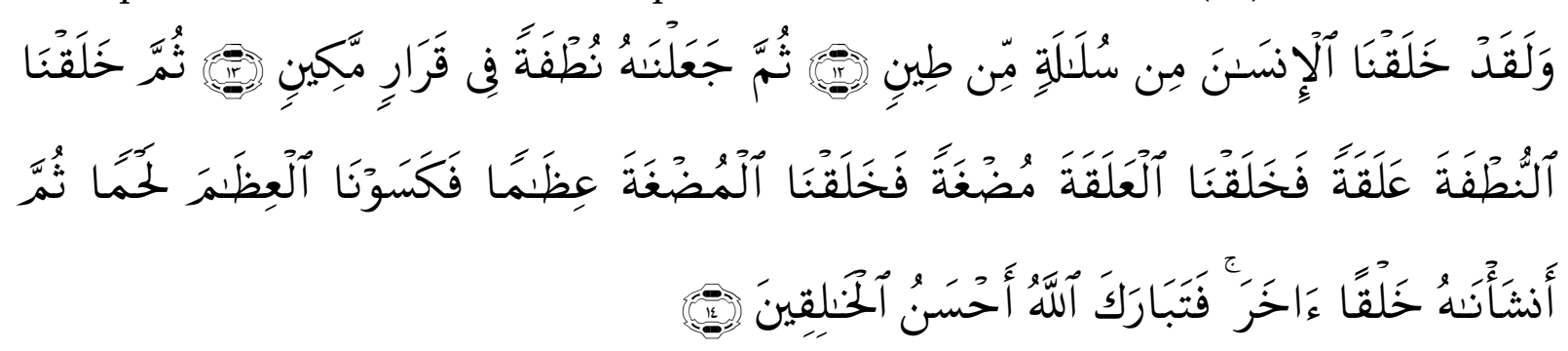

12. Dan Sesungguhnya Kami telah menciptakan manusia dari suatu saripati (berasal) dari tanah.

13. Kemudian Kami jadikan saripati itu air mani (yang disimpan) dalam tempat yang kokoh (rahim).

14. Kemudian air mani itu Kami jadikan segumpal darah, lalu segumpal darah itu Kami jadikan segumpal daging, dan segumpal daging itu Kami jadikan tulang belulang, lalu tulang belulang itu Kami bungkus dengan daging. Kemudian kami jadikan Dia makhluk yang (berbentuk) lain. Maka Maha sucilah Allah, Pencipta yang paling baik. 
Secara ringkas dapat dilihat siklus kejadian manusia. Manusia berasal dari tanah, tanah yang menghasilkan tanaman dan buah-buahan dimakan oleh manusia, menjadi saripati air (sperma) selanjutnya terjadi pembuahan dalam rahim, lahir manusia untuk hidup di atas tanah permukaan bumi sampai ajalnya dan kembali ke asalnya di kubur dalam tanah.

\section{Eksistensi Manusia}

Melihat asal kejadian manusia ia terlahir dari dua hal ikat yang berbeda yaitu:

1. Debu/tanah

2. Ruh (spirit) suci ${ }^{40}$

Kedua unsur ini merupakan simbol-simbol, debu tanah adalah simbol kerendahan, kemiskinan, kekotoran dan kelemahan lainnya, sedangkan Ruh (spirit) Tuhan adalah simbol kesucian dan keagungan. Debu tanah dan simbol spirit suci adalah dua dimensi dengan dua kecenderungan masing-masing:

$>$ Dimensi debu tanah membawanya menukik ke arah bawah kepada strategi sedimenter ke dasar hakikatnya yang rendah

$>$ Dimensi ruh (spirit) suci cenderung mendaki naik ke puncak spiritual tertinggi menuju zat yang suci.

Manusia yang eksis dengan menyandang ahsan al taqwim (احسن تقويم) tampil dengan kesamaptaan "Bentuk fisik yang tegak lurus (tidak merayap)" dengan memiliki akal dan pemahaman " 41 bentuk fisik dan psikis yang terbaik menyebabkan fungsinya juga berjalan dengan baik pula.

Kehadiran manusia yang ahsan al taqwim yang mempunyai fisik dan jiwanya diharapkan tetap memelihara keseimbangan. Keseimbangan untuk melaksanakan pengabdiannya kepada Allah sebagai hamba-Nya dan mengatur dan memelihara sesama manusia dan alam raya sebagai khalifah Allah.

Sebagai hamba Allah QS. Al Dzariyat (51): 56

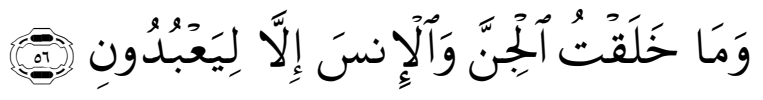

Dan sebagai khalifah Allah, QS Al An'am (6): 165

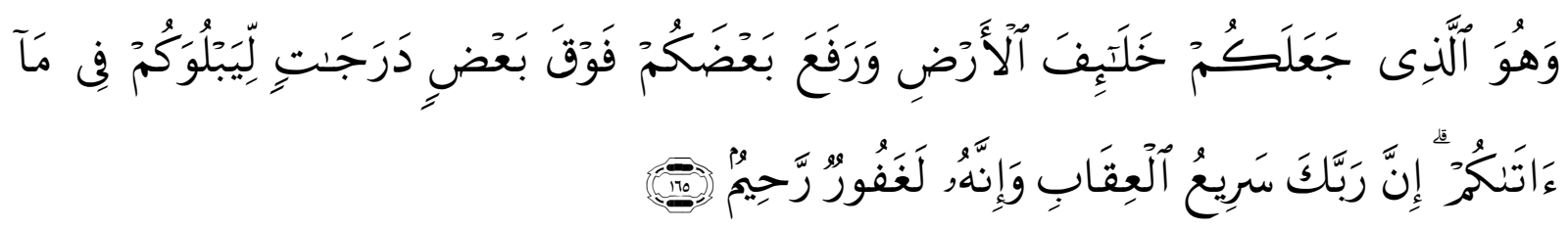

"Dan Dia lah yang menjadikan kamu penguasa-penguasa di bumi dan Dia meninggikan sebahagian kamu atas sebahagian (yang lain) beberapa derajat, untuk mengujimu tentang apa

\footnotetext{
${ }^{40}$ Lihat kandungan QS. Al Hijr (15): 28,29 dan lihat Ali Shariati, Man and Islam diterjemahkan Amin Rais dengan judul, Tugas Cendekiawan Muslim, (Jakarta: Raja Grafindo Persada, 1995), h.6

${ }^{41}$ Al Ragib Al Asfahani, Mufradat Alfaz al Quran, h.93 dan Lihat M. Quraish Shihab, Tafsir Surat Pendek, h.741
} 
yang diberikan-Nya kepadamu. Sesungguhnya Tuhanmu Amat cepat siksaan-Nya dan Sesungguhnya Dia Maha Pengampun lagi Maha Penyayang.

Terdapat tiga unsur pokok yang harus dijalani manusia yaitu:

a. Manusia sebagai makhluk

b. Bumi tempat manusia

c. Berbagai tugas yang harus dilaksanakan

Manusia memiliki status ganda yang seiring bersamaan yaitu sebagai hamba Allah (Abd.Allah) dan sekaligus sebagai pengemban tugas pengganti Allah (khalifah Allah. Sebagai hamba Allah ( عبد الله ( ) manusia taat menjalankan apa yang diperintahkan Allah serta menjauhi segala larangan-Nya secara ikhlas dan konsisten, sebagai khalifah Allah di muka bumi, manusia diberikan kebebasan untuk memilih berupaya dan berperan untuk mensejahterahkan manusia serta memelihara kelestarian dan kedamaian dunia.

Sekaitan dengan maksud ini kiranya patut menyimak suatu "warning" (peringatan) dan Sayyed Husein Nasr; Islam And the Environmental Crisis, yang dikutip A.Qadir Gassing "Tidak ada makhluk yang lebih berbahaya di muka bumi ini dibandingkan khalifah Allah yang tidak lagi menganggap dirinya Abd.Allah"43.

Sebagai sosok keturunan Adam yang dimuliakan Tuhan (al-Mukarram) manusia yang masih menyandang predikat baik antara lain sebagai ulu al albab yakni manusia dalam spectrum warna dalam kriteria etis, mampu mensinergikan ketajaman pikir kedalaman zikir. Namun demikian manusia juga memiliki keterbatasan dan kelemahan ${ }^{44}$ terutama dalam menepis dahsyatnya godaan setan ${ }^{45}$ dan godaan bendabenda lainnya baik dalam hubungan vertikal dengan sang pencipta (hablum min Allah) maupun hubungan horizontal sesame manusia (hablun min al nas).

Demikian pula siklus alami akan membatasi perjalanan hidupnya yang singkat, seperti tertera dalam QS. Al Rum (30): 54

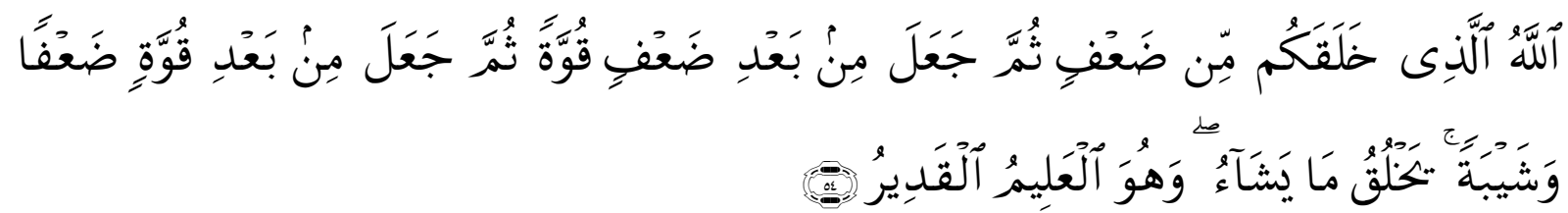

"Allah, Dialah yang menciptakan kamu dari Keadaan lemah, kemudian Dia menjadikan (kamu) sesudah Keadaan lemah itu menjadi kuat, kemudian Dia menjadikan (kamu) sesudah kuat itu lemah (kembali) dan beruban. Dia menciptakan apa yang dikehendaki-Nya dan Dialah yang Maha mengetahui lagi Maha Kuasa".

\footnotetext{
${ }^{42}$ Lihat M. Quraish Shihab, Tafsir al Amanah, (Pustaka Kartini, 1992), h.50

${ }^{43}$ H.A. Qadir Gassing, Fiqih Lingkungan, (Makassar: IAIN/UIN Alauddin, 2005), h.14

${ }^{44}$ Lihat misalnya QS. Al Maarij (70): 19-21

${ }^{45}$ Lihat misalnya QS. Al A'raf (71): 16-71
} 
Ayat ini memberikan tausiyah, mau izahah sekaligus tadzakirah kepada manusia pelakon pada garis edar umur dan ajal "Al thufulah al ihtilam al syuyukhah"46 yakni masa kanak-kanak yang polos, masa dewasa yang prima dan kembali ke masa tua yang renta dan selanjutnya kembali ke asal penciptaannya tanah. Untuk itu manusia dituntut untuk mengisi seoptimal mungkin pada masa prima "quwwah" dengan amal secara kualitas serta bermakna untuk kehidupan dunia dan kehidupan akhirat yang abadi.

\section{E. PENUTUP}

Dari uraian di atas, dapat ditarik beberapa kesimpulan penting antara lain:

1. Manusia adalah makhluk ciptaan Tuhan yang berinduk dari Adam. Manusia ini wujudnya terlihat jelas yang mampu berbicara, berpikir dan berkomunikasi dengan sesamanya dalam komunitas bermasyarakat. Asal kejadian Adam berbeda dengan asal kejadian manusia secara keseluruhan. Adam diciptakan secara khusus dari tanah, sedangkan manusia berasal dari saripati berasal dari tanah (sulalah min tin) kemudian menjadi air mani (nutfah), kemudian menjadi segumpal darah ('alaqah) kemudian menjadi segumpal daging (mudgah), kemudian menjadi tulang belulang ('izam), kemudian dibungkus dengan daging (lahm), kemudian menjadi bayi. Bayi tumbuh menjadi dewasa, dewasa tumbuh menjadi tua renta selanjutnya wafat dan dikebumikan kembali ke asal kejadiannya.

2. Manusia bisa tinggal menetap lama hanya dipermukaan bumi. Manusia eksis di pentas kehidupan dengan memiliki beberapa predikat yang baik antara lain sebagai ahsan al taqwim, sebagai ulu al albab yang menjadikan spektrum warna yang eksklusif dan tampil beda di antara makhluk lainnya, namun secara kodrati manusia pun memiliki kelemahan dan keterbatasan. Manusia diberikan amanah untuk berperan ganda sebagai khalifah Allah dan sebagai hamba Allah yang harus mampu disinerjikan secara seimbang dalam hubungan vertikal kepada sang pencipta ( habl min Allah) dan hubungan horizontal kepada sesama manusia (habl min al nas) serta makhluk lainnya di alam raya ini.

\footnotetext{
${ }^{46}$ Lihat Mahmud bin Umar Al Zamakhsyari, Tafsir Al Kasysyaf, V (t.t: Dar Al Fikr), h.226-227
} 


\section{Daftar Pustaka}

Alquran al Karim

Abu Zayd, Nashr, Rethingking the Quran, To wards a Humanistic Hermeneutic, Amsterdam: Humanistic Press, 2004

Abd. Baqi, Muh Fuad, Al-Mu'jam al-Mufahras Li alfaz Al-Qur'ā̄. Beirut: Dār al-Fikr, 1992

Al-Akkad, Abas Mahmud. Al-Falsafah Al-Qurani, Kairo: Dār al-Hilal, t.th.

Al Așfahanī, al Ragib, Mufradat Alfaz Al Quran, Beirut: Dar al-Syamiyah, 1992

Ali, Othman, The Concept of Man in The Writing of El Ghazali, Kairo: Dar El-Maarif

Baidhawy, Zakiuddin. Al Ruju' lla Al Quran: Dari kekebalan Fondasionalisme Menuju Pencerahan Hermeneutis, Malang: UMM Press, 2004

Bintu Syathi, Aisyah Abd.Rahman, Manusia dalam Prespektif Al Quran: Dari kekebalan Fondasionalisme Menuju Pencerahan, Jakarta: Pustaka Firdaus, 1999

Bucaille, Maurice, what is the Origin of Man, The Answer of Science and The Holy Scriptures, diterjemahkan Rahmani Astuti, Asal Usul Manusia menurut Bibel, Al Quran dan Sains, Bandung: Mizan, 1998

Gassing, A. Qadir, Fiqih Lingkungan, Makassar: UIN Alauddin, 2005

Leahay, Louis, Manusia Sebuah Misteri, Sintesa Filosofis tentang Makhluk Paradoksal, Cet.II, Jakarta: Gramedia, t.th.

Al-Maragī, Ahmad Mustafa. Tafsir al-Marā̄ì̄ Juz I. Mesir: Mustafā al-Babīal-Halabī wa Aulāiuh, 1985

Madkour, Ibrahim, The Concept of Man in Islamic Tought, London: t.p., 1996

Nasution, Harun, Islam Rasional, Bandung: Mizan, 1996

Qardhawy, Yusuf. Al 'Aqlu wa Al Ilmu, Diterjemahkan Abd.Hayyie Kattani, et.al, Al

Quran Berbicara tentang Akal dan Ilmu Pengetahuan, Jakarta: Gema Insani Press, 1998

Raharjo, Dawam, Paradigma Al Quran, Metodologi tafsir dan Kritik Sosial, Jakarta: PSAP Muhammadiyah, 2005

Salim, Abd.Muin, Metodologi Tafsir, Sebuah Rekonstruksi Epistimologis, Memantapkan Keberadaan Ilmu Tafsir Sebagai Ilmu. Ujungpandang: IAIN Alauddin, 1999

---------, Fitrah Manusia dalam Al Quran. Ujungpandang: Lembaga Studi Kebudayaan Islam, 1990

Al Huquq al Insaniyah fi al Quran al Karim. Makassar: Lembaga a Mu'tamar al Dauli/International Conference, 1-3 June, 2001

Konsepsi Kekuasaan Politik dalam Al Quran. Jakarta: PT. Raja Grafindo, 1994

Sarwar, H.G, Filsafat Al Quran, Jakarta: Rajawali Pers, 1990

Shariati, Ali, Man and Islam, Jakarta: Raja Grafindo Persada, 1995

Shihab, M. Quraish, Membumikan al-Qur'an, Bandung: Mizan, 1992

-, Wawasan al-Qur'an, Bandung: Mizan, 1996

, Tafsir al-Amanah, Jakarta: Pustaka Kartini, 1992 
Soejoeti, Zalbawi, et.al., Islam dan Iptek, Jakarta: PT. Raja Grafindo Persada, 1998 Toba'toba'I, The Holy Quran and The Science of the Nature, diterjemahkan Agus Efendi dengan Judul, Filsafat Sains Menurut al Quran, Bandung: Mizan, 1998 Yusuf Musa, Muhammad, Al-Qur'an wa Al Falsafah, Mesir: Dar Al-Ma'arif, 1996 Zakariya, Abi al Husain Ahmad Bin Faris, Maqayis Al-Lugah, t.t.: Dar al Fikr, t.th Al Zarkasyi, Al Burhan fi Ulum Al Quran, Mesir: Dar Ihya al Kutub al Arabiyah, t.th. Al Zumakhsyari, Tafsir Al Kasysyaf. V, t.t.: Dar al Fikr, t.th. 